\title{
Cross-Sector Partnerships to Address Social Issues: Challenges to Theory and Practice
}

\author{
John W. Selsky \\ University of South Florida -Lakeland, 3433 Winter Lake Road, Lakeland FL 33803 \\ Barbara Parker* \\ Albers School of Business \& Economics, Seattle University, 901 12th Avenue, Seattle, WA 98122
}

\begin{abstract}
Project-based cross-sector partnerships to address social issues (CSSPs) occur in four "arenas": business-nonprofit, business-government, government-nonprofit, and trisector. Research on CSSP is multidisciplinary, and different conceptual "platforms" are used: resource dependence, social issues, and societal sector platforms. This article consolidates recent literature on CSSPs to improve the potential for cross-disciplinary fertilization and especially to highlight developments in various disciplines for organizational researchers. A number of possible directions for future research on the theory, process, practice, method, and critique of CSSPs are highlighted. The societal sector platform is identified as a particularly promising framework for future research.
\end{abstract}

Keywords: partnership; cross sector; societal sectors; social issues; public-private alliances

Collaborative activities have become more prominent and extensive in all sectors of many nations in the past 25 years, resulting in a "stunning evolutionary change in institutional forms of governance" since the 1980s (Alter \& Hage, 1993: 12). One type of collaborative engagement is partnerships among business, government, and civil society— the three main societal

$\dagger$ The authors thank Daniel Feldman and an anonymous reviewer for helpful feedback on this article, and Samanthi Gunawardana for research assistance. The first author thanks the College of Management at the University of Massachusetts-Boston for support during the writing. The order of authorship is random; both authors contributed equally.

*Corresponding author. Tel.: 206-726-9798.

E-mail address: parker@seattleu.edu

Journal of Management, Vol. 31 No. 6, December 2005 849-873 DOI: $10.1177 / 0149206305279601$

() 2005 Southern Management Association. All rights reserved. 
sectors-that address social issues and causes (Austin, 2000; Gray, 1989; Sternberg, 1993; Stone, 2000; Young, 1999). In these cross-sector social-oriented partnerships, or CSSPs, organizations jointly address challenges such as economic development, education, health care, poverty alleviation, community capacity building, and environmental sustainability. The number of CSSPs has grown very rapidly in recent years (Berger, Cunningham, \& Drumwright, 2004; Crane, 2000; Elkington \& Fennell, 2000; Klitgaard \& Treverton, 2003), both in advanced and developing economies (de Oliveria \& Tandon, 1994). Observers note CSSPs are a growing organizational imperative (Austin, 2000; Kanter, 1998; Korten, 1998; Waddock \& Smith, 2000) but are a "poorly understood phenomenon" (Googins \& Rochlin, 2000: 133).

There are competing definitions of CSSPs (Nelson \& Zadek, 2000). Early on, Waddock characterized social partnerships as inherently cross-sectoral:

the voluntary collaborative efforts of actors from organizations in two or more economic sectors in a forum in which they cooperatively attempt to solve a problem or issue of mutual concern that is in some way identified with a public policy agenda item. (1991: 481-482)

For purposes of this review, CSSPs are defined as cross-sector projects formed explicitly to address social issues and causes that actively engage the partners on an ongoing basis. Such projects may be "transactional" - short-term, constrained, and largely self-interest orientedor "integrative" (Austin, 2000) and "developmental" (Googins \& Rochlin, 2000; Wymer \& Samu, 2003)—-longer term, open-ended, and largely common-interest oriented. Hence, the ambit of this review of CSSPs is narrower than routine relationships between and among the sectors, such as conventional arm's-length corporate philanthropy to the nonprofit sector, purchase-of-service contracts between government and the nonprofit sector, or collaborative policy-level efforts that arise periodically to "fix" social ills. As is typical in a new and evolving field, CSSP terminology varies; authors refer to social partnerships (Nelson \& Zadek, 2000; Waddock, 1991; Warner \& Sullivan, 2004), intersectoral partnerships (Waddell \& Brown, 1997), social alliances (Berger et al., 2004), issues management alliances (Austrom \& Lad, 1989), and strategic partnerships (Ashman, 2000).

It is appropriate to consolidate research on CSSPs at this point because their numbers are growing (Elkington \& Fennell, 2000; Klitgaard \& Treverton, 2003), the needs they address are increasingly complex, their impact is significant at local and global levels, they have important implications for organizational learning (London, Rondinelli, \& O'Neill, 2005), and studies of them are proliferating across a number of academic disciplines. The main research challenge we see is that studies of CSSPs emerge from various disciplines such as organization studies, public policy and administration, economics, nonprofit management, health care, education, and the natural environment. This review demonstrates that researchers in these disciplines use different theories and approaches. Consolidation of the multidisciplinary literature may help management researchers advance the agenda on CSSPs within organization studies.

Many practical barriers currently impede CSSP research. These partnerships differ greatly in size, scope, and purpose. They can range from dyads to multiparty arrangements, local to global levels, short- to long-term time frames, and totally voluntary to fully mandated. Moreover, organizations in every sector face changing pressures and evolving public expectations that encourage them to partner across sectors. Demands for corporate social responsibility 
encourage businesses to partner, nonprofits are motivated by demands for improved efficiency and accountability, and governments are encouraged to provide more benefits and services while being both less intrusive and more transparent. This review illustrates that when actors from different sectors focus on the same issue, they are likely to think about it differently, to be motivated by different goals, and to use different approaches. Finally, sources of concern for social issues tend to be multifaceted, spilling over traditional boundaries of organizations, sectors, and nations (Waddell, 2005). For example, health care and education are relatively well institutionalized in the public sectors of many nations, but there is considerable variation worldwide in the involvements of corporate and nonprofit organizations with those issues.

The following review of CSSPs begins with a general introduction to relevant research based on three conceptual "platforms" distinguished by their goal and interest orientations. The review then analyzes four "arenas" where CSSPs emerge: at the intersection of the business and nonprofit sectors, government and business sectors, government and nonprofit sectors, and at their conjoint intersection. Each arena is reviewed using the device of chronological stages. Finally, five main directions for future research are elaborated, focusing on the theory, process, practice, method, and critique of CSSPs. In this review, we use the terms nonprofit organization, nongovernmental organization (NGO), and civil society organization interchangeably.

\section{Platforms for Examining CSSPs}

The management and organization research is grounded in one of two analytic "platforms" for studying social partnerships: resource dependence and social issues. We supplement these with literature from other disciplines, which points to lacunae in organizational studies of CSSPs and yields a third platform, which we call societal sector.

\section{The Resource Dependence Platform}

Some literature explores the nature, evolution, and conceptualization of partnerships, alliances, and joint ventures from the perspective of meeting organizational needs or solving organizational problems. Core arguments are that organizations collaborate because they lack critical competencies they cannot develop on their own or in a timely fashion (Child \& Faulkner, 1998) and because their environments are more uncertain. This includes some of the strategy literature (e.g., Contractor \& Lorange, 1988; Faulkner \& deRond, 2000) and that part of the literature on collaboration dealing with new ways for organizations to acquire expertise and access to needed resources (Barringer \& Harrison, 2000; Gomes-Casseres, 1996; Trist, 1983), to cope with turbulence in their environments (Emery \& Trist, 1965; Gray, 1985; Selsky, 1991), and to gain competitive advantage (Andriof \& Waddock, 2002; Pasquero, 1991). Recent research on nonprofit organizations also uses a resource dependence framework (Hudock, 1995; Lister, 2000). This literature also includes stakeholder studies that use the firm as the unit of analysis, for example, emphasizing a firm's responsiveness to outside

constituencies and pressures. However, this literature is rather weak in its consideration of social issues; for example, Barringer and Harrison's (2000) Journal of Management review on 
interorganizational relations does not mention the ability to address social issues together as a "potential advantage" of them (p. 385).

The source of the social partnership idea in this literature on collaborative interorganizational relations is that businesses become more socially responsible to address stakeholder demands and develop or sustain a competitive advantage. Social partnerships here are conceived in a narrow, instrumental, and short-term way; they are viewed as a way to address organizational needs with the added benefit of addressing a social need. This view confirms sectoral distinctions, focusing on "minimizing interorganizational dependencies and preserving the organization's autonomy" (Gray \& Wood, 1991: 7). We will call this a resource dependence platform.

\section{The Social Issues Platform}

Literature on social issues management (e.g., Austrom \& Lad, 1989; Dutton \& Dukerich, 1991) explores the nature and evolution of social issues. This includes early work on social problem solving (e.g., McCann, 1983) as well as stakeholder literature focused on institutional fields, social issues, or policy sectors. In this literature, organizations and interest groups are seen as stakeholders of issues, not of organizations (Waddell, 2005). This also includes literature on collaboration and corporate social responsibility that explores why and how businesses should contribute resources toward addressing larger social or public issues (e.g., Andriof \& Waddock, 2002; Gray, 1989; Waddock \& Post, 1995). One argument is that rapid information exchange is increasing awareness of global as well as local dimensions of social issues. Gaps between public expectations of an organization or policy sector and its actual performance can then arise, spawning public issues (Post, Lawrence, \& Weber, 2002) and stimulating beliefs that government, business, and nonprofit actors should address social issues. External pressures from interest groups and public opinion can encourage or force managers to pay attention to these issues (Andriof \& Waddock, 2002; Greening \& Gray, 1994; Oliver, 1991).

Collaboration in this literature is defined as "a temporary social arrangement in which two or more social actors work together toward a single common end requiring the transmutation of materials, ideas, and/or social relations to achieve that end" (Roberts \& Bradley, 1991: 212). The partners intend to retain organizational autonomy while joining forces to tackle a shared social problem.

In the social issues literature, the source of the social partnership idea is that environmental turbulence generates unintended consequences; some of these manifest as social issues or "metaproblems" that exceed the scope of single organizations (Chevalier, 1966; Trist, 1983; Westley \& Vredenburg, 1991). By definition, these metaproblems are poorly defined (Trist, 1983; Waddock, 1991) and tend to fall through the cracks of prevailing institutional arrangements. As such, they need to get dealt with in multi-institutional collaborative endeavors (Gray, 1989; Trist, 1983; Waddell, 2005) that can improve the chances of addressing them successfully. Collaboration also helps the stakeholders of issues and metaproblems to shape and steer them more efficiently (Levy \& Oviatt, 1989). We will call this a social issues platform. 
The above two platforms for CSSP research are found in the organizational literature. In the resource dependence platform, organizations voluntarily partner primarily to serve their own interests (e.g., acquire needed resources) and secondarily to address a social concern. In the social issues platform, the issue is paramount, collaboration is either mandated or voluntary, and the partnership is designed to be issue focused. Increasingly in business-nonprofit and businessgovernment partnerships, issues are selected because they are, or are shaped to be, strategic, that is, supporting the core mission of the corporate partner (Elbers, 2004; Utting, 2002).

\section{The Societal Sector Platform}

A third platform for CSSP research is found in literature generally outside organization studies. The general argument is that new relationships between governments, businesses, and civil society organizations are blurring the boundaries between sectors, or "spheres" (Prakash, 2002; O'Riain, 2000). "Each sphere is multiply embedded within the others. Their boundaries cannot be clearly drawn, as each is intertwined with the others" (O'Riain, 2000: 191). Intersectoral blurring occurs when an organization in one sector adopts or captures a role or function traditionally associated with another sector, such as when governments contract out social welfare functions to nonprofits or businesses (Wolch, 1990) to produce "hybrid governance" (Klitgaard \& Treverton, 2003; see also Kramer, 2000).

Several contemporary forces encourage sectoral blurring. Reductions in government support and changes in philanthropic giving encourage nonprofits to generate revenues with commercial activities (Weisbrod, 1997). Factors like privatization and loss of public confidence have weakened governments at all levels, forcing them to rely more on business and civil society to provide public goods and services (Ashman, 2000; Googins \& Rochlin, 2000; Klitgaard $\&$ Treverton, 2003). Businesses need to answer to broader and more global constituents than previously, and these new stakeholders demand greater citizenship behaviors on a variety of issues (Waddock \& Smith, 2000).

The effects of intersectoral blurring are recognized more in partnership literature outside of organization studies. Authors tend to acknowledge tensions around power and identity that occur in the partnership process, as well as the contested roles and functions performed by each sector. "The relations among [the sectors] are inevitably tense, due to the inherent dilemmas of reconciling market, society, and state in a capitalist economy" (O'Riain, 2000: 191).

In this literature, the source of the social partnership idea is a growing sense that traditional sector solutions cannot address certain challenges and therefore must be enhanced by learning and borrowing from organizations in other sectors. Two logics are at work here: A substitution logic is that each sector has its own "natural" roles and functions in society, but one sector can substitute for another if the natural sector fails to provide the expected product. In contrast, a partnership logic is that the sectors are naturally inclined to partner with each other to address emergent societal issues (Linder \& Rosenau, 2000; see also Salamon, 1987; Young, 2000). Partnership logic is the conceptual wellspring of public-private partnerships as well as "third way" governance concepts, discussed in CSSP Arenas 2 and 3 below. We will call this a societal sector platform. 
This platform examines distinctive features of the main societal sectors such as values, motivations, and modes of operation, as well as their changing and blurred roles and functions. It also emphasizes the central role of organizational learning as an absorptive process (London et al., 2005). Learning transforms sectoral actors such that even when a partnership ends, participating organizations retain a new way of thinking about their mission, activities, and sectoral identity (Waddock, 1991).

\section{Organizing Research on CSSPs}

\section{Arenas of CSSPS}

As an operational device for this review, we divide the world of CSSPs into four arenas.

- Arena 1 represents partnerships between nonprofit organizations and businesses that encompass social issues and causes. They tend to center on environmental issues and economic development initiatives but also address health, equity, and education issues.

- Arena 2 represents partnerships between governments and businesses. The main form here is the public-private partnership (e.g., Rosenau, 2000a). They tend not to concentrate directly on social issues or causes but on infrastructure development and public services such as water and electricity that have important social implications.

- Arena 3 represents partnerships between governments and nonprofit organizations. This encompasses contracting out of public services and "third way" public policy approaches (Salamon, 1995). Studies in this arena tend to concentrate on job development and welfare.

- Arena 4 represents partnerships that involve actors from all three sectors. This arena focuses on large-scale national or international multisector projects, but subnational projects are also included. Studies in this arena tend to focus on economic and community development, social services, environmental concerns, and health.

The many thousands of cross-sector partnerships that operate at subnational levels (e.g., region, province, city, neighborhood; Nelson \& Zadek, 2000) often operate beneath the radar of researchers' attention (e.g., Otiso, 2003). Reports on empirical studies of CSSPs appear to be better reported in advanced economies than developing ones. Much CSSP research is part of company and foundation databases, conference publications, and Web sites that are not well integrated with the academy (e.g., see www.ccic.ca and www.jsi.com/idr/). This review aims to bring these disparate sources together better to illuminate findings on CSSPs for interested organizational researchers.

\section{Stages of CSSPS}

Researchers almost universally agree CSSPs can be examined according to chronological stages, and a number of stage models have been proffered (e.g., Googins \& Rochlin, 2000; Gray, 1989; Waddell \& Brown, 1997; Westley \& Vredenburg, 1997). However, the number of stages, variables examined within each stage, and nomenclature vary. 
One group of studies focuses on formation activities. Westley and Vredenburg argued that "participants must first successfully identify the problem, which includes finding a common definition, generating a variety of information, making a joint commitment to collaborate, identifying and legitimizing critical stakeholders, finding an appropriate convener, and identifying initial resources" (1997: 382). Motivations often are perceived to be an important precondition to collaboration (Greening \& Gray, 1994).

A second group of research clusters around CSSP implementation activities such as governance, structure, and leadership characteristics, as well as behavioral dynamics such as culture, communication, and relationship development.

A third research cluster examines outcomes from CSSPs. These include measurable project results and intangible outcomes such as system capacity for learning and change. A fourth cluster examines factors that can influence activities at more than one stage, such as stakeholder roles, power, and trust. Within each arena we use the chronological device of the above three stages and introduce stakeholder, power, and trust issues as they arise within each stage.

\section{Arena 1: Business-Nonprofit Partnerships}

Currently, a "partnership craze" among businesses (McAdoo, 2001) is tempered by nonprofits' cautious optimism (Elbers, 2004) or even outright opposition (Milne, Iyer, \& Gooding-Williams, 1996) for partnering with businesses. Despite their concerns, many nonprofits now view cross-sector partnerships as a necessary tactic (Murphy \& Bendell, 1999). In general, businesses are more attracted to direct-impact partnerships, such as education, environmental sustainability, or job development, than to those with indirect impacts, such as social mobilization, advocacy, or good governance (Ashman, 2001; Hutchinson, 2000). In recent years, the range and scope of partnership issues has widened (Aspen Institute, 2002) to embrace local and national concerns as well as global ones. At international and global levels, many partnerships are encouraged by supranational umbrellas such as the Prince of Wales International Business Leaders Forum or U.N. agencies such as UNICEF.

\section{Formation}

Growing within-sector competition for resources (Weisbrod, 1997; Young, 1999) and public calls for accountability (Lawrence \& Hardy, 1999; Waddock \& Smith, 2000) generate external pressures for all organizations to consider new alternatives. Partner motivation is a frequent topic for research in the formation stage because motivational differences are believed to derail collaborative intent (e.g., Gricar, 1981). Huxham and Vangen (1996) suggested three motivation levels: metagoals or the common cause, goals of each partner, and goals of specific individuals involved. Research focuses most on the middle category. A recurring theme regarding partner goals is that nonprofits' motives tend to be altruistic (Milne et al., 1996), whereas businesses partner to pursue self-interests (Iyer, 2003) like enhancing corpo-

rate image (Alsop, 2004; Zammit, 2004), garnering social capital and accessing existing networks (Millar, Choi, \& Chen, 2004); selling products (Burlingame \& Young, 1996); and attracting, motivating, and retaining desirable employees (Lewin \& Sabater, 1996). Partner 
and individual reasons to partner often involve a mix of self-interest and altruism (Agle, Mitchell, \& Sonnenfeld, 1999; Hutchinson, 2000; Sharma, Vredenburg, \& Westley, 1994). Although most studies of metagoals assume nonprofits and businesses have different priorities (Lewis, 1998; Sagawa \& Segal, 2000; Waddell \& Brown, 1997; Westley \& Vredenburg, 1991), recent research reexamines that assumption. For instance, nonprofits may view partnerships with businesses as a way to influence social change (Fabig \& Boele, 1999) or to become more important institutional actors (Doh \& Teegen, 2002).

This literature also examines how both internal and external stakeholders affect organizational willingness to partner. The organizational literature generally views stakeholder management as a means to an end. Those that adopt this view might be expected to pursue partnerships if they produce "the best prospective outcome for the firm" (Berman, Wicks, Kotha, \& Jones, 1999). External stakeholders may encourage or discourage partnerships. For example, Nasi, Nasi, Phillips, and Zyglidopoulos (1997) found that forestry company managers were extremely sensitive to major stakeholders, who often forced them to acknowledge and balance profitability and environmental preservation. On the other hand, external stakeholders sometimes object to negotiated partnerships (Lawrence \& Hardy, 1999) as occurred in a nascent partnership between the Canadian supermarket chain Loblaws and a national nonprofit advocacy group called Pollution Probe (Westley \& Vredenburg, 1991).

Trust at the formation stage of Arena 1 CSSPs is viewed as an input to a collaborative relationship (Hardy, Philips, \& Lawrence, 1998; Iyer, 2003); it is the by-product of prior trustful social interactions (Ring \& Van de Ven, 1994). However, trust can mean different things and operate differently in the corporate and nonprofit sectors (Parker \& Selsky, 2004). In general terms, trust in business traditionally is based on constrained contractual exchanges, whereas trust in the nonprofit sector is traditionally based on solidarity with the mission or on shared values.

\section{Implementation}

The preponderance of research on Arena 1 CSSPs concentrates on interrelated implementation activities such as partnership building and maintenance, governance mechanisms, and managerial requirements. Trust, power, and stakeholder relations also are featured.

Implementing a shared or common vision among independent actors (Gray, 1989) typically means developing a common culture held together by shared values, common interests, and clear communication. The shared metagoal is one source of CSSP identity building (Hardy, 1994). Impediments to building a common partnership culture include different views on business and social priorities (Lewis, 1998; Waddell \& Brown, 1997), as well as traditions of hostility, distrust, or ignorance between businesses and civil society organizations (Bendell, 2000; Gray, 1985; Westley \& Vredenburg, 1991; Zammit, 2004). Nonprofits often are skeptical about business motivations (Covey \& Brown, 2001); they fear reputational damage should the CSSP fail (Brown, 1991) or the partner engage in ancillary activities the public deems unsavory (Rundall, 2000). Crucial to developing a common partnership culture is clear communications, which can be complicated by sectoral differences. For instance, when nonprofit workers use words like governance, they are connoting something far more "intense, per- 
sonal, and immediate" than such words connote in the business world (Billis, 1993: 325). Poor communication can also occur when partners fail to clearly express their intentions (Rondinelli \& London, 2003) or underlying concerns (Millar et al., 2004; Parker \& Selsky, 2004; Rundall, 2000) or when they misunderstand the full scope of partner motivations (Long \& Arnold, 1995).

Difficulties in common culture development may be overcome by focusing on the metagoals, by realigning partners' expectations (Waddock \& Post, 1991; Westley \& Vredenburg, 1991), or by each partner giving credit to the other's experience and identity (Millar et al., 2004; Parker \& Selsky, 2004; Waddell, 2000).

Organizational structuring is the subject of several early studies (Gray, 1989; Hardy, 1994; Waddock, 1991; Westley \& Vredenburg, 1991), where the presence of an "enabling structure" such as a brokering or mediating organization is seen as a key factor facilitating collective action.

Institutional theory suggests that when there is high uncertainty about how to achieve specific outcomes, organizations are likely to emphasize standards and approve existing procedures. CSSP findings are mixed on this point. Siebel and Anheier (1990) argued that nonprofits are more likely to use informal coordination mechanisms and fewer formal controls than businesses or governmental entities. However, a study of 195 environmental partnerships found that nonprofit alliances with businesses were more formal than alliances with other nonprofits (Milne et al., 1996). Westley and Vredenburg believed CSSPs need not include "development of formal structures of authority, norms, and boundaries" when other "less formal organizing mechanisms may provide sufficient institutionalization for problem resolution" (1997: 394). Thus, various approaches to governance and structure are possible (Brown, 1991). Loss of control over decisions is a particular concern for nonprofits in CSSPs (Brown, 1991), leading some to argue for shared (Ashman, 2000; Austin, 2000) or consensus (Elbers, 2004) decision making. Managerial style and skills also affect implementation (Brown, 1991; Dorado \& Vaz, 2003; Waddock \& Post, 1995).

Maintaining legitimacy with external stakeholders is important to implementation. Nonprofit managers have considerable experience managing stakeholders (Billis, 1993; Covey \& Brown, 2001; Krashinsky, 1997). In a CSSP, they are able to identify and mobilize important stakeholders (Waddell, 2001), tend to involve more stakeholders in decision making (Elbers, 2004), and need to demonstrate that stakeholder interests are not being co-opted (Elbers, 2004). Partnerships may assemble complex sets of external stakeholders that were not there before the projects began (Covey \& Brown, 2001).

Internal stakeholders such as employees can resist or encourage negotiated agreements (Westley \& Vredenburg, 1991). For example, Covey and Brown (2001) observed that in a CSSP between the Environmental Defense Fund (EDF) and McDonald's, both worked with employees to encourage participation, and EDF also generated support from external stakeholders. In contrast, the Loblaws/Pollution Probe case mentioned above failed partly because Loblaws managed internal but not external stakeholders, whereas Pollution Probe consulted neither until after the agreement was finalized (Covey \& Brown, 2001). Finally, collaborative success may require a cultural shift in stakeholder attitudes (Gray, 1989) as sectoral actors step outside traditional boundaries to engage in new activities.

Discussions of power in the organizational literature on Arena 1 CSSPs examine resource disparities between businesses and nonprofit organizations (Elbers, 2004; Wymer \& Samu, 
2003). Large power imbalances are viewed as problematic because they may lead partners into political or opportunistic behavior that can serve one or both partners' interests at the expense of partnership performance (Doh \& Teegen, 2002; Parker \& Selsky, 2004). Some argue that power between partners does not need to be equal but that each needs to recognize the other's influence on their own well-being (Covey \& Brown, 2001; Waddell, 2000).

\section{Outcomes}

Outcomes of business-nonprofit partnerships have been measured at three levels: direct impact on the issue and its stakeholders; impact on building capacity, knowledge, or reputational capital that can attract new resources; and influence on social policy or system change. Direct impacts are most frequently measured, and more often in businesses than in nonprofits. Steckel and Simons (1992) generated a list of business-relevant outcomes including impact on sales, target market results, retailer and distributor response, and revenue-to-expense results. Direct performance measurement for nonprofit organizations is underdeveloped and ambiguous because "the relative simplicity of gauging a firm's profitability stands in sharp contrast to the complex, multidimensional social goals that, whether attained or not, often characterize nonprofits" (Weisbrod, 1998: 290). However, Steckel and Simons (1992) identified several possible measures, such as income and other resources that arise from collaboration.

Increased public awareness reflected in media coverage may be a measure of enhanced reputational or social capital (Steckel \& Simons, 1992). The nature of this social capital may vary depending on objectives sought; for example, "doing good" may help businesses earn social respect and trust (Millar et al., 2004). Businesses might learn how to gauge public sentiment more effectively from nonprofit managers, who tend to be protective of their organizations' and sector's reputations (Carbone, 1993).

Learning is an important outcome (London et al., 2005; Waddell, 1999). Different kinds of learning have been identified: interpersonal and administrative skills, technical skills in the issue area (e.g., how to combat environmental deterioration), reflective skills that can modify mind-sets and habits, and social learning that can lead to needed innovations (Waddell, 1999; see also Levy \& Oviatt, 1989). London et al. (2005) found that firms facing "a less coercive external environment and an internal context that supported relationships with environmental NPOs were more proactive in identifying opportunities to create new knowledge through alliances."

Examinations of how CSSPs affect policy or whole systems are limited. Brown and Ashman (1996) measured nonprofit outcomes according to the impact of multiparty development efforts on program reach, the number of people directly affected by collaborative activities, and resources committed for future program sustainability. Iyer (2003) posited that successful alliances may become the basis of trust that increases interest in future partnerships, suggesting that trust also can be a partnership output.

Overall, the literature on business/nonprofit CSSPs has a strong instrumental orientation that reflects the conventional resource dependence argument in organization studies. In partic-

ular, research on natural resource CSSPs suggests that many are responses to stakeholder demands for business accountability or are used as another tool for competitive advantage. 


\section{Arena 2: Government-Business Partnerships}

\section{Formation}

The iconic form in this arena is the public-private partnership (PPP), which has existed for 30 years (Linder \& Rosenau, 2000). A PPP is a set of "working arrangements based on a mutual commitment (over and above that implied in any contract) between a public sector organization with any organization outside of the public sector" (Bovaird, 2004: 199). (Note that this definition can also encompass studies in Arena 3.) Linder (1999) examined the multiple meanings behind the PPP term, its underlying premises, and ideological commitments from the right and the left. He argues that partnerships can be construed as both a political symbol and a policy tool. The meanings ascribed to PPPs include reforming how government functions, transforming public service delivery, shifting government risk in response to fiscal stringency, restructuring of the public service, and "moral regeneration" in bringing government closer to the "virtue" of the market.

A major source of motivations for Arena 2 partnerships is pressures for more efficient government, enshrined in the United States in the concept of "new public management," or NPM (Osborne \& Gaebler, 1992). The privatizations and outsourcings of government functions associated with NPM have resulted in a rapid increase in policy partnerships with the private sector (Linder \& Rosenau, 2000). (As noted earlier, general policy partnerships are outside the scope of this review of specific projects.) There has also been an explosion of specific projectbased partnerships driven by NPM ideas. Another source of motivations for Arena 2 partnerships is growing NGO activism directed at the business-government interface (Doh, 2003; Teegen \& Doh, 2003).

Milliman and Grosskopf (2004) examined collaboration between state and local government environmental agencies and business. They argued collaborations can be undertaken to facilitate development and transfer of new strategies and technology for environmental perfor-

mance. Focusing on the international health policy sector, Richter argued that PPPs are "not necessarily positively innovative, but that many of them carry large risks that are neither highlighted nor addressed due to the positive connotation of the term" (2004: 43). There may be "better and safer alternatives to the uncritical spread of the partnership-with-business model" that would serve the public interest more effectively (e.g., helping to fulfill people's fundamental right to a high standard of health).

\section{Implementation}

The literature in this area notes there are numerous institutional arrangements for government-business partnerships, including contracts and intergovernmental agreements. Pongsiri (2002) argued that the implementation of PPPs depends on successful development of legal procedures, agreements, and contracts that define the relationship clearly. Milliman and Grosskopf (2004) outlined how business and environmental regulatory agency managers can work together to create mutually beneficial agreements. They discussed existing problems 
between business and government agencies, success factors in negotiating agreements, and ideas for improving process.

\section{Outcomes}

In a field research study, Acar and Robertson attempted to

remedy the paucity of research on accountability in the context of ... [PPPs]. The most frequently cited difficulties associated with accountability in partnerships [between K-12 public schools and private and/or nonprofit organizations in the United States] were the availability of and access to information, sectoral and personal differences, and frequent changes in personnel, resources and partners. (2004: 331)

PPPs have been contested for almost as long as they have existed (Bovaird, 2004). Although most studies examine PPPs in a positive and instrumental way, some critique them on process or outcome grounds. Scholars question how to measure success; partnership continuance or longevity may not be valid indicators of success. In a review of the current state of PPPs, Rosenau (1999, 2000b) concluded they have substantial problems: They may decrease costs in the short term, but only if cost and efficiency are defined narrowly and externalities are discounted. They do not necessarily exhibit superior performance in terms of equity, access, or democracy. Moreover, they do not necessarily reduce regulation because government still must fulfill its roles as protector of the public good. Regarding accountability, public partners are the providers of last resort, although this could change if private partners gain more experience and partnering moves into more fully developed policy partnerships.

The gap between rhetoric and reality is a noteworthy theme (see Wettenhall, 2003). Some see PPPs as a covert form of privatization or public outsourcing, distancing government from its responsibilities (Dixon, Dogan, \& Kouzmin, 2004; Faranak, 2004). Dixon et al. are critical of the rhetoric of innovativeness in the PPP literature in terms of performance and its implications for governance: "Performance required of [PPPs] goes beyond market success and requires co-optation of strategic stakeholders, raising significant issues about corporate governance directions" (2004: 25). In a developing economies context, Faranak (2004) highlighted conceptual inconsistencies underlying PPPs that lead them to deliver results opposite to those they claim. Hence, he believed ambivalence and even deception may lie at the core of such partnerships. Dixon et al. (2004) pointed out that PPPs may advance the interests of the private sector through private rent-seeking opportunities, under the banner of sharing power with the poor and the state.

\section{Arena 3: Government-Nonprofit Partnerships}

\section{Formation}

A 1993 review by Farrington and Bebbington on sustainable agricultural development and technology found that existing literature on government-nonprofit partnerships fell into two 
categories: (a) discussions of the comparative advantage of state versus nonprofit organizations in fulfilling specific functions, with each filling the other's gaps, and (b) the social origins and history of nonprofits and their antagonistic relationships with the state and business sectors (see also Young, 2000). The authors concluded more research was needed regarding relationships between and within institutions, and this was, in fact, pursued after 1995. Moreover, their review dealt with nonprofits that form voluntarily and independently of the state. This is a marked difference from the literature that followed, which also included nonprofits created by the state. For example, Hodgson uses the term manufactured civil society to describe "groups that are formed and funded, at least initially, through some type of state initiative. Often these groups are directly answerable to the state and have to address certain criteria and meet targets set by government" (2004: 145). The terms shadow state (Wolch, 1990) and third party government (Mirabella \& Wish, 2001) have been used in similar ways. A theme of "third-way" partnerships, based on the same NPM principles (Osborne \& Gaebler, 1992) as in Arena 2, is evident in the public administration literature dealing with Arena 3. In third-way policies and governance, governments seek active engagement with civil society. The language of public-private partnerships, used extensively in Arena 2, is also used in Arena 3 studies (e.g., Deakin, 2002, in a U.K. context, and Jenei \& Vari, 2000, in a Hungarian context).

In their review, Farrington and Bebbington (1993) highlighted the inherent structural limitations of nonprofits acting alone and theorized the possibilities for state-nonprofit relationships. They argued that partnerships between the two sectors may not be enough and that linkages with the private business sector may afford greater scope and effectiveness of activity.

J. M. Brinkerhoff divided the literature on government-nonprofit partnerships into three streams; we include it as a formation theme because it deals with motivations and framings of Arena 3 partnerships. Normative literature views partnerships as ends in themselves. This literature "tak[es] the moral high ground," as it is seen as "the most ethically appropriate approach," encompassing empowerment and participation principles (2002: 20). Reactive literature typically is put forward by aid-giving bodies (e.g., World Bank) and states seeking to defend and move beyond past transgressions (as purported by the normative literature). In pragmatic and analytical literature, partnerships are viewed instrumentally, as an efficient and effective means of reaching objectives. This is accompanied by a how-to literature that tends to codify experiences but may overlook constraints and opportunities (2002: 21). This third stream draws on the business alliance literature as well as network theory, political economy, and NPM literatures.

Tensions over power and control are evident. Hodgson (2004) argued that the state's creation of manufactured civil society groups is a means of controlling the civil society sector. This can increase levels of frustrations and distrust between state and voluntary bodies and among groups themselves because governmental values are forced onto communities (see also Mirabella \& Wish, 2001). Farrington and Bebbington (1993) questioned why nonprofits maintained confrontational rhetoric in their dealings with the state, even when their relationships were collaborative and productive, and speculated whether this was due to anxieties over loss of identity. Lister (2000) questioned whether project-based development partnerships between nonprofits and powerful donors can actually be considered partnerships, given the 
wide power disparities. (Note these donors can be corporations, corporate foundations, or governments, so this critique could also be lodged in Arena 1.)

\section{Implementation}

Farrington and Bebbington (1993) discovered diverse and productive forms of interactions between nonprofits and the state, but finding a pattern among them was difficult. A range of informal and formal linkage mechanisms exist, with specific resources allocated to them. Structural (rather than operational) linkages are important as they allowed nonprofits to take part in decision making and resource allocation. However, the authors found a lack of planning or systematic thinking about government-nonprofit partnerships in general.

J. M. Brinkerhoff (2002: 25) derived a classification of government-nonprofit partnerships on the basis of dimensions of mutuality and organizational identity:

- Contracting: Specific organizational characteristics and/or distinctive contributions are sought by another organization to fulfill predetermined ends and means.

- Extension: One organization controls the partnership and its terms; the other organization has little independent identity. The partnership is an extension of the dominant organization.

- Co-optation and gradual absorption: One organization's identity is compromised by another.

Huxham and Vangen (1996) identified six "common themes" regarding the conduct of voluntary local community development projects; these concern goal setting, communication, negotiation, and other processes also discussed extensively in Arena 1. Several authors point to the crucial role of local government capacity in community partnerships (Lovrich, 2000; Martin, 1997; Smith, 1997).

Issues of power in the implementation phase are discussed. Boettke and Prychitko (2003) questioned whether nonprofit partnerships with the state are a positive development. They argued that the voluntary sector ceases to function properly when organizations within it partner with the state, given the latter's coercive powers. Democracy and equality are important concerns of local residents when partnering with local government around community development (Huxham \& Vangen, 1996) and correctional reform (Lovrich, 2000) initiatives.

\section{Outcomes}

This body of work includes how-to and outcome-based studies, with an emphasis on success factors. It generally uses case studies to draw out lessons learned or key factors contributing to the success of partnerships; see D. W. Brinkerhoff (1999), Krishna (2003), Jennings and Moore (2000), and Langholz and Quotes (2002). These include goal setting and service delivery (Linden, 2002), types of capabilities needed (D. W. Brinkerhoff, 1999; Mirabella \& Wish, 2001), roles of key personnel and interpersonal relationships (Shaw, 2003), governance, and other issues. 


\section{Arena 4: Trisector Partnerships}

\section{Formation}

Brem (1999) listed many cross-sectoral initiatives around the world, and Nelson and Zadek (2000) outlined many in Europe. Some authors do not distinguish between bisector and trisector partnerships, so it is sometimes difficult to separate studies into the appropriate categories.

Similar to the other arenas, partner motivations for trisector actors are viewed as a blend of self-interest and altruism (Pasquero, 1991; Warner \& Sullivan, 2004; Westley \& Vredenburg, 1991). However, recent research suggests that a major motivation is partner awareness of the growing number of complex and multilayered social problems that cut across societies (Pasquero, 1991) combined with the desire of organizations in all sectors to contribute to global problem solving (Warner \& Sullivan, 2004). It is evident in this literature that the social problem or issue, not any organization, has stakeholders. Often the most important stakeholders are organizations whose leaders have come to believe that amelioration of complex social challenges will most likely come from joint action (Brown, Khagram, Moore, \& Frumkin, 2000; Domask, 2003; Murphy \& Bendell, 1999; Warner \& Sullivan, 2004). External pressures such as NGO-driven social movements that direct attention to certain social issues may also be important (Doh, 2003).

Negotiating rights and responsibilities as partners jockey to manage these issues may reveal tensions and contradictions (Waddell, 2000) over self- versus common interest (Pasquero, 1991; Westley \& Vredenburg, 1991). A distinguishing feature of trisector partnerships is the frequent presence of "bridging" organizations to convene or manage the crosssector relationships. These structures help to create opportunities to improve the social issue, but conflicting participant demands can generate antagonism or tensions (Brown, 1991; Cook, Dodds, \& Mitchell, 2003; Waddock, 1991).

\section{Implementation}

This literature frequently examines the roles of governments or quasi-governmental organizations in enhancing trisector partnerships (Martin, 1997; see Smith, 1997, for local government). As in the other arenas, stages of partnerships are an important topic (Lowdes \& Skelcher, 1998; Magee, 2003; Pasquero, 1991; Samii, Van Wassenhove, \& Bhattacharya, 2002; Waddell \& Brown, 1997). There is a clear focus on governance (Lowdes \& Skelcher, 1998; Warner \& Sullivan, 2004; White, 2001). Martin's (1997) examination of governance in local U.K.-based trisector partnerships stresses the importance of clear communication in partnership development. A new language may be needed to "re-present" governance issues (White, 2001), including terminology and shared values (Westley \& Vredenburg, 1991).

The trisector arena emphasizes the effects of multiple and complex interdependencies (Hardy, 1994; Pasquero, 1991) involving many stakeholders (Warner \& Sullivan, 2004). In trisector partnerships addressing global issues, it is likely that at least some interests of impor- 
tant stakeholders will not be represented in the partnerships. When there are fewer and more homogeneous stakeholders, values are more likely to converge (Hardy, 1994) than in diverse multiparticipant partnerships. The latter situations may benefit from intermediaries or "bridges" that can negotiate bilaterally with key stakeholders or serve as links among them (Westley \& Vredenburg, 1991).

Trust is cited as a critical contributor to partnership activities (Waddell, 2000), often resting on partner assurance of their own and others' legitimacy (Pasquero, 1991). Businesses are viewed as having more power because of their greater resources (Ashman, 2000), but others argue that resource-based power may be less important to a trisector partnership than the capacity for mobilizing a constituency around the issue (Waddell, 2000), for implementing decisions (Pasquero, 1991), or for achieving goals.

Managerial skills for trisector partnerships are similar to those discussed in the other arenas, such as ability to understand diverse perspectives (Westley \& Vredenburg, 1991), access to an extensive network, stature to attract key individuals and mobilize resources, and ability to leverage the media (Waddock \& Post, 1991, 1995).

\section{Outcomes}

A persistent challenge in trisector research is establishing outcome criteria because they differ for corporate, government, and civil society organizations (Brown et al., 2000). Many studies examine both tangible and intangible outcomes (Westley \& Vredenburg, 1991). Generally, researchers view CSSPs in Arena 4 positively (Herman, 2001; Otiso, 2003; Waddell \& Brown, 1997), but others are more critical, noting for example that the complex goals of such projects often are unrealistic and unachievable (Boguslaw, 2002; Turcotte \& Pasquero, 2001).

Among tangible outcomes identified in trisector studies are industry certification standards such as the Pan European Forest Certification Scheme and the Rain Forest Alliance certification. Labor unions, community, governments, foundations, and employers-essentially stakeholders of trisector partnerships-help set such standards (Herman, 2001). Warner (2004) noted four tangible outcomes that can enhance competitive advantages for businesses: community building to resolve future local disputes, community recognition as a company of choice, reduced risk from negative publicity, and increased attractiveness to prospective employees. Other tangible outcomes include new investments in community development that governments will not make and increased public revenue distribution or availability of public facilities within communities (Warner, 2004; Warner \& Sullivan, 2004). Methods to measure CSSP outcomes are just starting to receive research attention (see Dowling, Powell, \& Glendinning, 2004; Mitchell, Shankleman, \& Warner, 2004).

Trisector research also explores intangible and indirect outcomes. Partnerships can give direction to the relevant metaproblem (Turcotte \& Pasquero, 2001) and result in partners learning new ways of framing the problem and potential solutions (Boguslaw, 2002; Huxham \& Vangen, 2000). In dynamic, evolving coalitions, partners may receive or perceive only indirect benefits because direct benefits of action may only be evident in the long run (Waddock, 1991). Research also indicates that trisector partnerships can have mixed outcomes; stakeholders of environmental partnerships observed that some mitigated serious issues, but other 
partnerships aggravated such issues (Leach, Pelky, \& Sabatier, 2002). Finally, the complex goals of trisector projects may turn out to be counterproductive because they shift the balance of power in resolving public policy issues toward corporate interests (Cook et al., 2003; Zammit, 2004).

\section{Research Directions}

This review yields several promising directions for future research on CSSPs. First, the conceptual underpinnings of this multidisciplinary field need to be strengthened. Organizational research appears to be unevenly split between the resource-dependence and social-issue platforms. The former is associated with strategy concepts with their view of focalorganization-based stakeholders; the latter is associated with collaboration concepts with their view of issue-based stakeholders. However, both sets of concepts have drawbacks in applications to CSSPs. Strategy theories may suffer from an instrumental emphasis and certain assumptions (e.g., dependency in a relationship is the reverse of power; the focal organization is the essential unit of analysis). Collaboration theory may not adequately explain collaborative processes or governance structures in complex domains involving many and diverse actors (Westley \& Vredenburg, 1997). As an alternative conceptual underpinning governance theory from the public policy literature-with its emphasis on mutuality in decision making among partners, democratic control and accountability among stakeholder sets, and a strong role for civil society (Wettenhall, 2003)_holds promise. It is already beginning to be used as a framework for understanding CSSPs in several disciplines (Detomasi, 2002; O'Brien, Goetz, Scholte, \& Williams, 2000).

A related conceptual issue concerns the way CSSPs are modeled. A simple input-output systems model appears to be a background assumption in much CSSP research. Such models underlie the identification of functionally useful dimensions of these partnerships and causal factors affecting (successful) partnership outcomes. While certainly useful for practice and for building theory in a new field, such models tend to neglect the embeddedness of social processes within the larger institutional structures studied in institutional theory, as well as processes of nonlinear emergence as studied in complexity theory (see White, 2001). Regarding institutional theory, the insights that CSSPs have stakeholders and that those stakeholders can shape the form and evolution of partnerships (Doh, 2003) have received little attention to date. Teegen and Doh (2003) pointed to promising research in examining NGOs as potential enablers ("stakegivers") and obstructors ("staketakers") with regard to parties interested in business-government relationships. Structural power asymmetries in the social context of health (Scott \& Thurston, 2004) and development (Lister, 2000) partnerships have recently been identified, but much more research is needed in this area. Social movement concepts hold promise because changing public expectations contribute to the framing of social issues and can drive the formation of CSSPs; see Lounsbury, Ventresca, and Hirsch (2003) in institutional theory and O'Brien et al. (2000) in governance theory.

Researchers might also benefit from using complexity models to explore processes of nonlinear emergence in and around CSSPs. For example, attention might focus on the impact of cross-sector partnerships on sustainability or resiliency of large-scale social systems that part- 
nerships are associated with. Such models might also shed new light on strategic issues management by focusing on feedback loops. Illustrative questions are How do partnerships change the institutional fields in which they are embedded? Should social issues be viewed as endogenous (a product of interactions between organizations that choose to address them) or as exogenous (welling up in society as social movements beyond the control of organizations and then "impacting" on them)? Using institutional and complexity models in CSSP research would challenge prevailing input-output models and help draw attention to neglected aspects of these partnerships.

Second, there are several research issues concerning the practice of partnerships. Illustrative questions are How can researchers capture the messiness of partnership practice in more complex models, as discussed above? How can they be more theoretically precise while still offering practical and relevant guidance in this applied field? How can they gauge the influence of social movements and trends as part of changing public expectations regarding all sectors and their roles and functions? A related issue is the distinctiveness of CSSPs. In this review, practical challenges to forming CSSPs were identified due to differences among the sectors in goal orientations, culture, language, and other factors. More research is needed on how CSSPs differ from within-sector partnerships. In what ways is the accumulated knowledge about partnerships drawn from studies within sectors applicable to CSSPs? In addition, contingency approaches might focus on effective forms of governance, advocacy, and intervention to facilitate different kinds of CSSPs.

Third, certain process issues would reward research attention. Literature on the several arenas of CSSPs tends to focus on macro issues, but very few examine micro issues like leadership required at sectoral interfaces (but see Huxham \& Vangen, 2000; Waddock \& Post, 1995) or intercultural processes (but see Parker \& Selsky, 2004). Studies of how partners overcome (or exploit) sectoral differences to learn about their social issue, learn from each other, or encourage stakeholder learning would be valuable contributions. Research on CSSPs based in different nations is virtually untouched, so a host of cross-cultural issues await attention, especially as CSSPs address more transnational and global issues. Such issues include examination of the embeddedness of particular projects in national cultural contexts and acculturation challenges in cross-national partnerships.

Fourth, the methods used to study CSSPs need further development. Much of the recent organizational literature views social partnerships as instrumental means of achieving various (common or complementary) objectives. However, the reporting of CSSPs has generally been in terms of case studies examining short-term partnerships or examining them during a short period of time. This is consistent with the field's pragmatic orientation but leaves gaps in understanding long-term impacts, consequences, and learning. Hence, there is a need for more longitudinal research to capture the evolution, coevolution, development, and demise of CSSPs. Such methods would be more likely to uncover complex emergent processes, as discussed above. Moreover, after many productive years of relying on case studies, the field is ripe for theory building by way of large-scale empirical research.

Finally, more political and critical perspectives on CSSPs would reward research attention. Most organizational literature is favorable toward these entities and discusses them in functional, normative, and managerial terms. The assumption is that CSSPs can help organizations achieve their goals (aligned with the resource dependence platform) or help managers to come 
together to solve society's problems (aligned with the social issues platform). There is little attention paid to the underlying institutional dynamics, including power, that set the stage for the way social issues are defined and worked on (aligned with the societal sector platform). CSSPs have a political dimension that is underresearched.

Power inequalities may emerge within social partnerships, such that less powerful partners (e.g., a local environmental advocacy organization) may feel its identity or culture threatened by more powerful partners (such as a large corporation). Closer examination of the distribution and balance of power both within partnerships and in embedding contexts is needed. One possible research direction would be to frame CSSPs in multiple ways within the same study, for example, by juxtaposing the three platforms. The societal sector platform appears to be the most appropriate one for examining the political dimension of CSSPs. That platform contributes to organizational research by articulating a partnership logic where partners jointly take ownership of a social issue and integrate that issue into their core set of activities and goals (Linder \& Rosenau, 2000). In contrast, the resource dependence and social issues platforms derive from a substitution logic, in which organizations seek access to a social issue and mobilize resources to address it in a partnership project, but the issue and the project are kept separate from core activities and goals. Using a societal-sector platform as a framing device would generate different kinds of questions from the usual kind of questions produced using the resource dependence and social issues platforms. Examples are the following: How does the CSSP reflect the identities and the strategies of the partners? How are the identities of the partners "multiply embedded" with each other (O'Riain, 2000)? How does the CSSP help each partner to learn, determine what to learn, and how to learn? How does it help the partners to address issues of trust, power, and control?

Our survey was limited in two ways. Because of resource limitations, it was confined to research in the English language, and it emphasized journals in management and organization studies to be responsive to Journal of Management readers.

We did not strive to produce an integrated theory of CSSPs by synthesizing themes from the diverse literatures because we believe the state of this field is still too underdeveloped. CSSPs by nature involve real-world challenges that naturally cut across organizational and sectoral boundaries. They present a challenge to academic tendencies to create and enforce disciplinary silos. Within and outside organization studies, researchers argue for integrative approaches to studying intractable social/economic challenges (see Harrison \& Freeman, 1999; O'Riain, 2000). Hence, a major contribution of this review may be introducing a new, interdisciplinary platform for studying CSSPs to organizational researchers, namely, the societal sector platform.

\section{References}

Acar, M., \& Robertson, P. J. 2004. Accountability challenges in networks and partnerships: Evidence from educational partnership in the United States. International Review of Administrative Sciences, 70(2): 331-344.

Agle, B. R., Mitchell, R. K., \& Sonnenfeld, J. 1999. Who matters to CEOs? An investigation of stakeholder attributes and salience, corporate performance, and CEO values. Academy of Management Journal, 42(5): 507-526.

Alsop, R. J. 2004. The 18 immutable laws of corporate reputation. New York: Free Press.

Alter, K., \& Hage, J. 1993. Organizations working together. Newbury Park, CA: Sage. 
Andriof, J., \& S. Waddock. 2002. Unfolding stakeholder engagement. In J. Andriof, S. Waddock, B. Husted, \& S. Rahman. Unfolding stakeholder thinking: Theory, responsibility and engagement: 19-42. Sheffield, UK: Greenleaf.

Ashman, D. 2000. Promoting corporate citizenship in the global South: Towards a model of empowered civil society collaboration with business. IDR Reports, 16(3). http://www.jsi.com/idr/IDRreports.htm

Ashman, D. 2001. Civil society collaboration with business: Bringing empowerment back in. World Development, 29: 1097-1113.

Aspen Institute. 2002. The nonprofit sector and business: New visions, new opportunities, new challenges. Washington, DC: The Aspen Institute Nonprofit Sector Strategy Group.

Austin, J. 2000. The collaborative challenge. San Francisco: Jossey-Bass.

Austrom, D., \& Lad, L. 1989. Issues management alliances: New responses, new values, and new logics. Research in Corporate Social Performance and Policy, 11: 233-255.

Barringer, B., \& Harrison, J. 2000. Walking a tightrope: Creating value through interorganizational relationships. Journal of Management, 26(3): 367-403.

Bendell, J. 2000. Working with stakeholder pressure for sustainable development. In J. Bendell (Ed.), Terms for endearment: 14-30. Sheffield, UK: Greenleaf.

Berger, I., Cunningham, P., \& Drumwright, M. 2004. Social alliances: Company/nonprofit collaboration. California Management Review, 47(1): 58-90.

Berman, S. L., Wicks, A. C., Kotha, S., \& Jones, T. M. 1999. Does stakeholder orientation matter: The relationship between stakeholder management models and firm financial performance. Academy of Management Journal, 42(5): 488-506.

Billis, D. 1993. What can nonprofits and businesses learn from each other? In D. Hammock \& D. Young (Eds.), Nonprofit organizations in a market economy: 319-341. San Francisco: Jossey-Bass.

Boettke, P. J., \& Prychitko, D. 2003. An independent non-profit sector prone to failure? An Austrian school perspective of the Salamon Paradigm and Lomann Challenge. Global prosperity initiative working paper no. 24, Mercatus Center, George Mason University. http://www.mercatus.org/pdf/materials/447.pdf

Boguslaw, J. E. 2002. Social partnerships and social relations. London: Routledge.

Bovaird, T. 2004. Public-private partnerships: From contested concepts to prevalent practice. International Review of Administrative Sciences, 70(2): 199-215.

Brem, M. 1999. Mapping corporate citizenship: A survey of global, national, and local initiatives. In L. Regelbrugge (Ed.), Promoting corporate citizenship: 27-69. Washington, DC: CIVICUS.

Brinkerhoff, D. W. 1999. Exploring state-civil society collaboration: Policy partnerships in developing countries. Nonprofit and Voluntary Sector Quarterly, 28(1): 59-86.

Brinkerhoff, J. M. 2002. Government-nonprofit partnership: A defining framework. Public Administration and Development, 22(1): 19-30.

Brown, L. D. 1991. Bridging organizations and sustainable development. Human Relations, 44(8): 807-831.

Brown, L. D., \& Ashman, D. 1996. Participation, social capital, and intersectoral problem solving: African and Asian cases. World Development, 24(9): 1467-1479.

Brown, L. D., Khagram, S., Moore, M. H., \& Frumkin, P. 2000. Globalization, NGOs, and multisectoral relations. In J. S. Nye Jr. \& J. D. Donahue (Eds.), Governance in a globalizing world: 271-298. Washington, DC: Brookings Institution Press.

Burlingame, D., \& Young, D. R. 1996. Corporate philanthropy at the crossroads. Indianapolis: Indiana University Press.

Carbone, R. 1993. Marketplace practices and fundraising ethics. In D. Hammock \& D. Young (Eds.), Nonprofit organizations in a market economy: 294-315. San Francisco: Jossey-Bass.

Chevalier, M. 1966. A wider range of perspectives in the bureaucratic structure. Ottawa, Canada: Commission on Bilingualism and Biculturalism.

Child, J., \& Faulkner, D. 1998. Strategies of cooperation: Managing alliances, networks, and joint ventures. London: Oxford University Press.

Contractor, F. J., \& Lorange, P. 1988. Why should firms cooperate? The strategy and economics basis for cooperative ventures. In F. J. Contractor \& P. Lorange (Eds.), Cooperative strategies in international business: 3-30. Lexington, MA: Lexington Books. 
Cook, B., Dodds, C., \& Mitchell, W. 2003. Social entrepreneurship—False promises and dangerous forebodings. Australian Journal of Social Issues, 38(1): 57-73.

Covey, J., \& Brown, L. D. 2001. Critical cooperation: An alternative form of civil society-business engagement. IDR Reports, 17(1). http://www.jsi.com/idr/IDRreports.htm

Crane, A. 2000. Culture clash and mediation. In J. Bendell (Ed.), Terms for endearment: 163-177. Sheffield, UK: Greenleaf.

de Oliveria, M. D., \& Tandon, R. 1994. Citizens: Strengthening global civil society. Washington, DC: CIVICUS

Deakin, N. 2002. Public-private partnerships: A UK case study. Public Management Review, 4(2): 133-147.

Detomasi, D. 2002. International institutions and the case for corporate governance: Toward a distributive governance framework? Global Governance, 8(4): 421-442.

Dixon, J., Dogan, R., \& Kouzmin, A. 2004. The dilemma of privatized public services: Philosophical frames in understanding failure and managing partnership terminations. Public Organization Review, 4(1): 25-46.

Doh, J. P. 2003. Nongovernmental organizations, corporate strategy, and public policy: NGOs as agents of change. In J. P. Doh \& H. Teegen (Eds.), Globalization and NGOs: 1-18. Westport, CT: Praeger.

Doh, J. P., \& Teegen, H. 2002. Nongovernmental organizations as institutional actors in international business: Theory and implications. International Business Review, 11: 665-684.

Domask, J. 2003. From boycotts to global partnerships: NGOs, the private sector, and the sruggle to protect the world's forests. In J. P. Doh \& H. Teegen (Eds.), Globalization and NGOs: 157-186. Westport, CT: Praeger.

Dorado, S., \& Vaz, P. 2003. Convenors as champions of collaboration in the public sector: A case from South Africa. Public Administration and Development, 23: 141-150.

Dowling, B., Powell, M., \& Glendinning, C. 2004. Conceptualizing successful partnerships. Health and Social Care in the Community, 12(4): 309-317.

Dutton, J., \& Dukerich, J. 1991. Keeping an eye on the mirror: Image and identity in organizational adaptation. Academy of Management Journal, 34(3): 517-554.

Elbers, W. 2004. Doing business with business: Development NGOs interacting with the corporate sector. http:// www.evertvrmeer.nl/download.do/id/100105391/cd/true/

Elkington, J., \& Fennell, S. 2000. Partners for sustainability. In J. Bendell (Ed.), Terms for endearment: 150-162. Sheffield, UK: Greenleaf.

Emery, F., \& Trist, E. 1965. The causal textures of organizational environments. Human Relations, 18: 21-32.

Fabig, H., \& Boele, R. 1999. The changing nature of NGO activity in a globalizing world: Pushing the corporate responsibility agenda. IDS Bulletin, 30: 58-67.

Faranak, M. 2004. Public-private partnerships: The trojan horse of neoliberal development . Journal of Planning Education and Research, 24(1): 89-101.

Farrington, J., \& Bebbington, A. (with Wellard, K., \& Lewis, D. J.). 1993. Reluctant partners? Non-governmental organizations, the state and sustainable agricultural development. London: Routledge.

Faulkner, D., \& de Rond, M. 2000. Perspectives on cooperative strategy. In D. Faulkner \& M. de Rond (Eds.), Cooperative strategy: Economic, business and organizational issues: 3-39. Oxford, UK: Oxford University Press.

Gomes-Casseres, B. 1996. The alliance revolution: The new shape of business rivalry. Cambridge, MA: Harvard University Press.

Googins, B., \& Rochlin, S. 2000. Creating the partnership society: Understanding the rhetoric and reality of crosssectoral partnerships. Business and Society Review, 105(1): 127-144.

Gray, B. 1985. Conditions facilitating interorganizational collaboration. Human Relations, 38: 911-936.

Gray, B. 1989. Collaborating. San Francisco: Jossey-Bass.

Gray, B., \& Wood, D. 1991. Collaborative alliances: Moving from practice to theory. Journal of Applied Behavioral Science, 27(1): 3-22.

Greening, D. W., \& Gray, B. 1994. Testing a model of organizational response to social and political issues. Academy of Management Journal, 37(3): 467-498.

Gricar, B. 1981. Fostering collaboration among organizations. In H. Meltzer \& W. R. Nord (Eds.), Making organizations humane and productive: 403-420. New York: John Wiley.

Hardy, C. 1994. Underorganized interorganizational domains: The case of refugee systems. Journal of Applied Behavioral Science, 30(3): 278-296. 
Hardy, C., Phillips, N., \& Lawrence, T. 1998. Distinguishing trust and power in interorganizational relations: Forms and facades of trust. In C. Lane \& R. Bachmann (Eds), Trust within and between organizations: 64-87. Oxford, UK: Oxford University Press.

Harrison, J., \& Freeman, R. E. 1999. Stakeholders, social responsibility, and performance: Empirical evidence and theoretical perspectives. Academy of Management Journal, 42(5): 479-485.

Herman, B. 2001. How high road partnerships work. Social Policy, 31(3): 11-19.

Hodgson, L. 2004. Manufactured civil society: Counting the cost. Critical Social Policy, 24(2): 139-164.

Hudock, A. 1995. Sustaining Southern NGOs in a resource-dependent environment. Journal of International Development, 7: 653-667.

Hutchinson, M. 2000, January. NGO engagement with the private sector on a global agenda to end poverty: A review of the issues. Background paper, Canadian Council for International Cooperation Policy Team. http:// www.ccic.ca/e/007/pubs_csr.shtml

Huxham, C., \& Vangen, S. 1996. Working together: Key themes in the management of relationships between public and non-profit organizations. International Journal of Public Sector Management, 9(7): 5-17.

Huxham, C., \& Vangen, S. 2000. Leadership in the shaping and implementation of collaboration agendas: How things happen in a (not quite) joined-up world. Academy of Management Journal, 43(6): 1159-1175.

Iyer, E. 2003. Theory of alliances: Partnership and partner characteristics. Journal of Nonprofit and Public Sector Marketing, 11(1): 41-57.

Jenei, G., \& Vari, A. 2000. Partnership between local government and the local community in the area of social policy: An Hungarian experience. Public Management, 2(2): 239-250.

Jennings, S., \& Moore, S. 2000. The rhetoric behind regionalization in Australian natural resource management: Myth, reality and moving forward. Journal of Environmental Policy and Planning, 2(3): 177-191.

Kanter, R. M. 1998. Six strategic challenges. World Link, 11(1): 28-34.

Klitgaard, R., \& Treverton, G. F. 2003, March. Assessing partnerships: New forms of collaboration. Washington, DC: IBM Endowment for the Business of Government: New Ways to Manage Series.

Korten, D. 1998. Globalizing civil society: Reclaiming our right to power. New York: Seven Stories Press.

Kramer, R. 2000. A third sector in the third millennium? Voluntas, 11(1): 1-23.

Krashinsky, M. 1997. Stakeholder theories of the non-profit sector: One cut at the economic literature. Voluntas, 8(2): 149-161.

Krishna, A. 2003. Partnership between local governments and community-based organisations: Exploring the scope for synergy. Public Administration and Development, 23(4): 361-371.

Langholz, J. A., \& Quotes, P. 2002. How industry, academia and a non-profit organization plan to create cash and conserve species. Corporate Environmental Strategy, 9(2): 145-154.

Lawrence, T., \& Hardy, C. 1999. Building bridges for refugees: Toward a typology of bridging organizations. Journal of Applied Behavioral Science, 35(1): 48-70.

Leach, W. D., Pelky, N. W., \& Sabatier, P. A. 2002. Stakeholder partnerships as collaborative policymaking: Evaluation criteria applied to watershed management in California and Washington. Journal of Policy Analysis and Management, 21(4): 645-670.

Levy, R., \& Oviatt, F., Jr. 1989. Corporate philanthropy. In Bill Cantor (Ed.), Experts in action: Inside public relations: 126-38. New York: Longman.

Lewin, D., \& Sabater, J. M. 1996. Corporate philanthropy and business performance. In D. F. Burlingame \& D. R. Young (Eds.), Corporate philanthropy at the crossroads: 105-126. Bloomington: Indiana University Press.

Lewis, D. 1998. Nongovernmental organizations, business, and the management of ambiguity. Nonprofit Management \& Leadership, 9(2): 135-151.

Linden, R. 2002. A framework for collaborating. Public Manager, 31(2): 3-6.

Linder, S. H. 1999. Coming to terms with the public-private partnership: A grammar of multiple meanings. The American Behavioral Scientist, 43(1): 35-51.

Linder, S. H., \& Rosenau, P.V. 2000. Mapping the terrain of the public-private policy partnership. In P. V. Rosenau (Ed.), Public-private policy partnerships: 1-18. Cambridge, MA: MIT Press.

Lister, S. 2000. Power in partnership? An analysis of an NGO's relationships with its partners. Journal of International Development, 12: 227-239.

Lohmann, R. A. 1992. The commons: New perspectives on nonprofit organizations and voluntary action. San Francisco: Jossey-Bass. 
London, T., Rondinelli, D. A., \& O'Neill, H. 2005. Strange bedfellows: Alliances between corporations and nonprofits. In O. Shenkar \& J. Reuer (Eds.), Handbook of strategic alliances: 353-366. Thousand Oaks, CA: Sage.

Long, F. J., \& Arnold, M. B. 1995. The power of environmental partnerships. New York: Dryden.

Lounsbury, M., Ventresca, M., \& Hirsch, P. 2003. Social movements, field frames and institutional emergence: A cultural-political perspective on U.S. recycling. Socio-Economic Review, 1: 71-104.

Lovrich, N. P. 2000. Policy partnering between the public and not-for-profit sectors. In P. V. Rosenau (Ed.), Publicprivate policy partnerships: 183-198. Cambridge, MA: MIT Press.

Lowdes, V., \& Skelcher, C. 1998. The dynamics of multi-organisational partnerships: An analysis of changing modes of governance. Public Administration, 76(2): 437-454.

Magee, M. 2003. Qualities of enduring cross sector partnerships in public health. American Journal of Surgery, 185(1): 26-30.

Martin, S. 1997. Leadership, learning and local democracy: Political dimensions of the strategic management of change. International Journal of Public Sector Management, 10(7): 534-546.

McAdoo, M. R. 2001. Tying the knot: The partnership craze. In Sustaining growth and bridging the divides: A framework for our global future: 40. Davos, Switzerland: World Economic Forum Annual Meeting Report.

McCann, J. 1983. Design guidelines for social problem solving interventions. Journal of Applied Behavioral Science, 19(2): 177-192.

Millar, C. C. J. M., Choi, C. J., \& Chen, S. 2004. Global strategic partnerships between MNEs and NGOs: Drivers of change and ethical issues. Business and Society Review, 109(4): 395-414.

Milliman, J., \& Grosskopf, J. 2004. Improving the regulatory enforcement settlement process: Applying collaborative solutions for businesses and environmental agencies. Environmental Quality Management, Spring: 25-43.

Milne, G. R., Iyer, E. S., \& Gooding-Williams, S. 1996. Environmental organization alliance relationships within and across nonprofit, business, and government sectors. Journal of Public Policy and Marketing, 15(2): 203-215.

Mirabella, R., \& Wish, N. B. 2001. University based educational programs in the management of nonprofit organizations: An updated census on US programs. Public Performance and Management Review, 25(1): 30-41.

Mitchell, J., Shankleman, J., \& Warner, M. 2004. Measuring the added value of partnerships. In Michael Warner \& Rory Sullivan (Eds.), Putting partnerships to work: 191-200. Sheffield, UK: Greenleaf.

Murphy, D. F., \& Bendell, J. 1999, August. Partners in time? Business, NGOs and sustainable development. UNRISD Discussion Paper 109. http://www.unrisd.org

Nasi, J., Nasi, S., Phillips, N., \& Zyglidopoulos, S. 1997. The evolution of corporate social responsiveness: An exploratory study of Finnish and Canadian forestry companies. Business \& Society, 36(3): 296-322.

Nelson, J., \& Zadek, S. 2000. Partnership alchemy: New social partnerships in Europe. Copenhagen, Denmark: The Copenhagen Centre.

O’Brien, J., Goetz, A. M., Scholte, J. A., \& Williams, M. 2000. Contesting global governance: Multilateral economic institutions and global social movements. Cambridge, MA: Cambridge University Press.

Oliver, C. 1991. Strategic responses to institutional processes. Academy of Management Review, 16: 145-179.

O'Riain, S. 2000. States and markets in an era of globalization. Annual Review of Sociology, 26: 187-213.

Osborne, D., \& T. Gaebler. 1992. Reinventing government. Reading, MA: Addison-Wesley.

Otiso, K. M. 2003. State, voluntary and private sector partnerships for slum upgrading and basic service delivery in Nairobi City, Kenya. Cities, 20(4): 221-229.

Parker, B., \& Selsky, J. 2004. Interface dynamics in cause based partnerships: An exploration of emergent culture. Nonprofit and Voluntary Sector Quarterly, 33(3): 458-488.

Pasquero, J. 1991. Supraorganizational collaboration: The Canadian environmental experiment. Journal of Applied Behavioral Science, 27(1): 38-64.

Pongsiri, N. 2002. Regulation and public-private partnerships. International Journal of Public Sector Management, 15(6): 487-495.

Post, J., Lawrence, A., \& Weber, J. 2002. Business and society: Corporate strategy, public policy, ethics. 10th ed. New York: McGraw-Hill.

Prakash, A. 2002. Beyond Seattle: Globalization, the nonmarket environment and corporate strategy. Review of International Political Economy, 9(3): 513-537.

Richter, J. 2004. Public-private partnerships for health: A trend with no alternatives? Development, 47(2): 43-48.

Ring, P., \& Van de Ven, A. 1994. Developmental processes of cooperative interorganizational relationships. Academy of Management Review, 19(1): 90-118. 
Roberts, N. C., \& Bradley, R. T. 1991. Stakeholder collaboration and innovation: A study of public policy initiation at the state level. Journal of Applied Behavioral Science, 27(2): 209-227.

Rondinelli, D. A., \& London, T. 2003. How corporations and environmental groups cooperate: Assessing cross-sector alliances and collaborations. Academy of Management Executive, 17(1): 61-76.

Rosenau, P. V. 1999. Introduction: The strengths and weaknesses of public-private policy partnerships. The American Behavioral Scientist, 43(1): 10-34

Rosenau, P. V. (Ed.). 2000a. Public-private policy partnerships. Cambridge, MA: MIT Press.

Rosenau, P. V. 2000b. The strengths and weaknesses of public-private policy partnerships. In Public-private policy partnerships: 217-241. Cambridge, MA: MIT Press.

Rundall, P. 2000. The perils of partnership: An NGO perspective. Addiction, 95(10): 1501-1504.

Sagawa, S., \& Segal, E. 2000. Common interest, common good. Boston: Harvard Business School Press.

Salamon, L. 1987. Of market failure, voluntary failure, and third-party government: Toward a theory of governmentnonprofit relations in the modern welfare state. Journal of Voluntary Action Research, 16(1/2): 29-49.

Salamon, L. 1995. Partners in public service: Government-nonprofit relations in the modern welfare state. Baltimore, MD: Johns Hopkins University Press.

Samii, R., Van Wassenhove, L. N., \& Bhattacharya, S. 2002. An innovative public-private partnership: New approach to development. World Development, 30(6): 991-1008.

Scott, C. M., \& Thurston, W. E. 2004. The influence of social context on partnerships in Canadian health systems. Gender, Work and Organization, 11(5): 481-506.

Selsky, J. 1991. Lessons in community development: An activist approach to stimulating inter-organizational collaboration. Journal of Applied Behavioral Science, 27(1): 91-115.

Sharma, S., Vredenburg, H., \& Westley, F. 1994. Strategic bridging: A role for the multinational corporation in Third World development. Journal of Applied Behavioral Science, 30(4): 458-476.

Shaw, M. M. 2003. Successful collaboration between nonprofit and public sectors. Nonprofit Management and Leadership, 14(1): 107-120

Siebel, W., \& Anheier, H. 1990. Sociological and political science approaches to the third sector. In H. Anheier \& W. Siebel (Eds.), The Third Sector: Comparative studies of nonprofit organizations: 7-20. New York: Walter de Gruyter.

Smith, S. R. 1997. Partnerships, community building, and local government. National Civic Review, 86(2): $167-174$.

Steckel, R., \& Simons, R. 1992. Doing best by doing good: How to use public purpose partnerships to boost corporate profits and benefit your community. New York: Dutton.

Sternberg, E. 1993. Preparing for the hybrid economy: The new world of public-private partnerships. Business Horizons, 36(6): 11-15.

Stone, M. 2000. Exploring the effects of collaborations on member organizations: Washington County's Welfare-toWork Partnership. Nonprofit \& Voluntary Sector Quarterly, 29(1): 98-119.

Teegen, H., \& Doh, J. P. 2003. Conclusion: Globalization and the future of nonprofit influence. In J. P. Doh \& H. Teegen (Eds.), Globalization and NGOs: 203-221. Westport, CT: Praeger.

Trist, E. L. 1983. Referent organizations and the development of interorganizational domains. Human Relations, 36 : 247-268.

Turcotte, M., \& Pasquero, J. 2001. The paradox of multistakeholder collaborative roundtables. Journal of Applied Behavioral Science, 37(4): 447-464

Utting, P. (Ed.). 2002. The greening of business in developing countries. London: Zed Books.

Waddell, S. 1999, August. Business-government-nonprofit collaborations as agents for social innovation and learning. Paper presented at the meeting of the Academy of Management, Chicago.

Waddell, S. 2000. New institutions for the practice of corporate citizenship: Historical, intersectoral, and developmental perspectives. Business and Society Review, 105(1): 107-126.

Waddell, S. 2001. The role of civil society in business strategy. The Corporate Ethics Monitor, July-August: 57-59.

Waddell, S. 2005. Societal learning and change. Sheffield, UK: Greenleaf.

Waddell, S., \& Brown, L. D. 1997. Fostering intersectoral partnering: A guide to promoting cooperation among government, business, and civil society actors. IDR Reports, 13(3). http://www.jsi.com/idr

Waddock, S. 1991. A typology of social partnership organizations. Administration \& Society, 22(4): $480-516$.

Waddock, S. A., \& Post, J. E. 1991. Social entrepreneurs and catalytic change. Public Administration Review, 51(5): 393-401. 
Waddock, S., \& Post, J. 1995. Catalytic alliances for social problem solving. Human Relations, 48(8): 951-973.

Waddock, S. A., \& Smith, N. 2000. Relationships: The real challenge of corporate global citizenship. Business \& Society Review, 105(1): 47-62.

Warner, M. 2004. Building blocks for partnerships. In M. Warner \& R. Sullivan (Eds.), Putting partnerships to work: 24-33. Sheffield, UK: Greenleaf.

Warner, M., \& Sullivan, R. 2004. Putting partnerships to work. Sheffield, UK: Greenleaf.

Weisbrod, B. A. 1997. The future of the nonprofit sector: Its entwining with private enterprise and government. Journal of Policy Analysis and Management, 16(4): 541-555.

Weisbrod, B. A. 1998. Conclusions and public-policy issues: Commercialism and the road ahead. In B. A. Weisbrod (Ed.), To profit or not to profit: 287-305. Cambridge, UK: Cambridge University Press.

Westley, F., \& Vredenburg, H. 1991. Strategic bridging: The collaboration between environmentalists and business in the marketing of green products. Journal of Applied Behavioral Science, 27(1): 65-90.

Westley, F., \& Vredenburg, H. 1997. Interorganizational collaboration and the preservation of global biodiversity. Organization Science, 8(4): 381-403.

Wettenhall, R. 2003. The rhetoric and reality of public-private partnerships. Public Organization Review, 3: 77-107.

White, L. 2001. Effective governance through complexity thinking and management science. Systems Research and Behavioral Science, 18(3): 241-257.

Wolch, J. R. 1990. The shadow state: Government and voluntary sector in transition. New York: The Foundation Center.

Wymer, W. W., \& Samu, S. 2003. Dimensions of business and nonprofit collaborative relationships. Journal of Nonprofit and Public Sector Marketing, 11(1): 3-22.

Young, D. R. 1999. Nonprofit management studies in the United States: Current developments and future prospects. Journal of Public Affairs Education, 5(1): 13-23.

Young, D. R. 2000. Alternative models of government-nonprofit sector relations: Theoretical and international perspectives. Nonprofit and Voluntary Sector Quarterly, 29(1): 149-172.

Zammit, A. 2004. Development at risk: Rethinking UN-business partnerships. South Centre and UNRISD joint publication. http://www.southcentre.org/publications/developmentatrisk/newrisk.pdf

\section{Biographical Notes}

John W. Selsky is an associate professor in management at the University of South Florida-Lakeland. Prior to accepting this position in 2005, he was at the University of Melbourne. His doctoral work at Wharton involved action research with a large, diverse partnership in the nonprofit sector in Philadelphia. His current research interests include environmental sustainability, collaborative strategies in highly turbulent environments, and the dynamics of waterfront labor disputes.

Barbara Parker is a professor of management in the Albers School of Business at Seattle University. Her research interests include cross-sector partnerships, globalization, diversity, service learning, and student learning outcomes from study abroad tours. She has published in a variety of journals, and her recent book is Introduction to Globalization and Business (2005, Sage). 